\title{
CDKN2BAS is associated with periodontitis in different European populations and is activated by bacterial infection
}

\author{
Arne S Schaefer, ${ }^{1}$ Gesa M Richter, ${ }^{1}$ Henrik Dommisch, ${ }^{2}$ Markus Reinartz, ${ }^{2}$ \\ Michael Nothnagel, ${ }^{3}$ Barbara Noack, ${ }^{4}$ Marja L Laine, ${ }^{5}$ Mathias Folwaczny, \\ Birte Groessner-Schreiber, ${ }^{7}$ Bruno G Loos, ${ }^{5}$ Søren Jepsen, ${ }^{2}$ Stefan Schreiber ${ }^{1}$
}

\begin{abstract}
- Additional data are published online only. To view these files please visit the journal online (http://jmg.bmj.com).
\end{abstract}

${ }^{1}$ Christian-Albrechts-University Kiel, Institute for Clinical Molecular Biology, Kiel, Germany

${ }^{2}$ Department of Periodontology, Operative and Preventive Dentistry, University of Bonn, Bonn, Germany

${ }^{3}$ University Medical Center

Schleswig-Holstein, Campus

Kiel, Institute of Medical

Informatics and Statistics, Kiel, Germany

${ }^{4}$ University Medical Center Carl Gustav Carus der Technischen Universität Dresden, Zentrum für Zahn-, Mund- und Kieferheilkunde, Poliklinik für Zahnerhaltung, Dresden, Germany

${ }^{5}$ Department of Periodontology, Academic Centre for Dentistry Amsterdam (ACTA), University of Amsterdam and VU University, Amsterdam, the Netherlands

${ }^{6}$ Department of Preventive Dentistry and Periodontology, University of Munich, Munich, Germany

University Medical Center Schleswig-Holstein, Campus Kiel, Department of Operative Dentistry and Periodontology, Kiel, Germany

\section{Correspondence to}

Dr Arne S Schaefer

Christian-Albrechts-University

Kiel, Institute for Clinical

Molecular Biology,

Arnold-Heller-Str. 3, 24105 Kiel,

Germany;

a.schaefer@ikmb.uni-kiel.de

Received 11 March 2010

Revised 8 July 2010

Accepted 15 July 2010

Published Online First

26 October 2010

\section{ABSTRACT}

Epidemiological studies have indicated a relationship between coronary heart disease (CHD) and periodontitis. Recently, CDKN2BAS was reported as a shared genetic risk factor of $\mathrm{CHD}$ and aggressive periodontitis $(\mathrm{AgP})$, but the causative variant has remained unknown. To identify and validate risk variants in different European populations, we first explored $150 \mathrm{~kb}$ of the genetic region of $C D K N 2 B A S$ including the adjacent genes CDKN2A and CDKN2B, covering 51 tagging single nucleotide polymorphisms (tagSNPs) in AgP and chronic periodontitis $(C P)$ in individuals of Dutch origin $(n=313)$. In a second step, we tested the significant SNP associations in an independent $\mathrm{AgP}$ and CP population of German origin $(n=1264)$. For the tagSNPs rs1360590, rs3217992, and rs518394, we could validate the associations with $\mathrm{AgP}$ before and after adjustment for the covariates smoking, gender and diabetes, with SNP rs3217992 being the most significant (OR 1.48, 95\% Cl 1.19 to $1.85 ; p=0.0004)$. We further showed in vivo gene expression of CDKN2BAS, CDKN2A, CDKN2B, and CDK4 in healthy and inflamed gingival epithelium (GE) and connective tissue (CT), and detected a significantly higher expression of CDKN2BAS in healthy CT compared to GE $(\mathrm{p}=0.004)$. After $24 \mathrm{~h}$ of stimulation with Porphyromonas gingivalis in Streptococcus gordonii pretreated gingival fibroblast (HGF) and cultured gingival epithelial cells (GECS), we observed a 25 -fold and fourfold increase of CDKN2BAS gene expression in HGFs $(p=0.003)$ and GECs $(p=0.004)$, respectively.

Considering the global importance of CDKN2BAS in the disease risk of $\mathrm{CHD}$, this observation supports the theory of inflammatory components in the disease physiology of CHD.

\section{INTRODUCTION}

Coronary heart disease (CHD) is the leading cause of death worldwide ${ }^{2}$ and is considered to be a complex multifactorial disease. Epidemiological studies have shown a significant correlation between periodontal health and the occurrence of cardiovascular events. ${ }^{34}$ Periodontitis and CHD are both strongly promoted by very similar environmental and behavioural risk factors, with smoking and diabetes being the most prominent. ${ }^{5-13}$ Furthermore, the same pathogenic bacterial strains were observed in both inflamed gingival tissue and atherosclerotic plaques. ${ }^{10} 14$ It has also been shown that periodontal treatment results in improvement of endothelial function, a marker for risk prediction of cardiovascular events. ${ }^{16}$ Recently, a major genetic susceptibility locus for CHD was identified by various genome wide association studies (GWAS). ${ }^{17-20}$ This locus is located within the chromosomal region 9p21.3, mapping to the large non-coding (nc) antisense RNA transcript CDKN2BAS, formerly called ANRIL. This association was verified by a subsequent meta-analysis ${ }^{9}$ and by a large scale replication study, ${ }^{21}$ making this genetic region the best replicated CHD associated risk locus to date. In addition, variants within this region were independently found to be associated with type 2 diabetes, ${ }^{2-24}$ abdominal aortic and intracranial aneurysms, ${ }^{25}$ ischaemic stroke, ${ }^{26}$ Alzheimer's disease and vascular dementia, ${ }^{27}$ and high grade glioma susceptibility. ${ }^{28}$ Recently, we demonstrated the association of a highly increased risk for aggressive periodontitis (AgP) with specific variants of CDKN2BAS. ${ }^{29}$ However, despite extensive fine mapping and functional studies, the causative variant and the functional role of $C D K N B A S$ has remained unknown. ${ }^{9} 30$ In recent years, long non-coding RNAs like CDKN2BAS have been recognised for their role in regulating gene expression by contributing to the recruitment of protein complexes to target genes in trans, and to provide an architectural matrix to retain the proteins at the repression site of the target gene. Unprecedented, a role in cis regulation of CDKN2A expression was very recently described for a new transcript of $C D K N 2 B A S$ that initiates upstream of the previously reported start site ${ }^{31}$ indicating a regulatory role for $C D K N 2 B A S$ in the context of cellular proliferation.

In the present study, we aimed to identify genetic risk variants of $C D K N 2 B A S$ that are shared by different European case-control populations of aggressive and chronic periodontitis. To this end, we covered $>150 \mathrm{~kb}$ with 51 tagging single nucleotide polymorphisms (tagSNPs) mapping to $C D K N 2 B A S$ and the adjacent cell cycle inhibitor genes $C D K N 2 A$ and $C D K N 2 B$. We explored the SNP associations in two populations of $\mathrm{AgP}$ and chronic periodontitis (CP) of Dutch origin $(n=313)$, and replicated the significant associations in two populations of $\mathrm{AgP}$ and $\mathrm{CP}$ of German origin $(\mathrm{n}=1264)$.

Recently, differential gene expression of CDKN2BAS in a variety of CHD relevant tissues, such as vascular endothelial cells, smooth coronary 
muscle cells, fibroblasts, and macrophages, has been demonstrated. ${ }^{30} 32 \quad 33$ To study the tissue specific expression in the gingiva, we quantified the mRNA transcription pattern of $C D K N 2 B A S, C D K N 2 A$ and $C D K N 2 B$ in healthy and inflamed human gingival tissue samples. Additionally, we studied the gingival expression of $C D K 4$, a cell cycle regulating kinase that is directly inhibited by CDKN2A and CDKN2B. To explore the possibility that both periodontitis and $\mathrm{CHD}$ share an inflammatory pathophysiology, we assessed the potential role of pathogenic bacteria in the transcriptional regulation of these genes in different gingival tissues.

\section{PATIENTS AND METHODS Study population}

The patient and control samples of the CP and AgP association studies were recruited across Germany and the Netherlands as previously described. ${ }^{34}$ Only individuals of German and Dutch ethnicity were included, judged upon the location of both parental birthplaces. Before the study, the genetic sub-structure of the German and Dutch populations had been assessed, ${ }^{35} 36$ indicating only negligible sub-structures and therefore allowing an analysis of the German and Dutch individuals in a single genetic study without the risk of substantial population stratification. A detailed description of the study population is given in table 1 and in the supplementary information. Informed written consent was obtained from all subjects recruited into this study. The study was approved by each institute's own ethical review board (Medical Ethical Committee, Universities of Bonn, Dresden, Kiel and Munich, and Medical Ethical Committee, Academic Medical Center, University of Amsterdam, The Netherlands).

\section{DNA extraction and genotyping}

Genomic DNA was extracted from blood (Invisorb Blood Universal Kit, Invitek, Berlin, Germany) or mouthwash samples, ${ }^{37}$ and was amplified by whole genome amplification (GenomiPhi, Amersham, Uppsala, Sweden). TagSNPs were selected from the CEU data of the International HapMap project (http://www.hapmap.org, NCBI build 36, 2008-03) using the Tagger feature ${ }^{38}$ of Haploview 4.0. ${ }^{39}$ TagSNPs were defined by pair-wise linkage disequilibrium tagging $\left(\mathrm{r}^{2}>0.8\right)$. Genotyping was carried out using the SNPlex and TaqMan Genotyping
System (Applied Biosystems, Foster City, California, USA) on an automated platform, using TECAN Freedom EVO and 96-well and 384-well TEMO liquid handling robots (TECAN, Männedorf, Switzerland). Genotypes were generated by automatic calling using the Genemapper 4.0 software (Applied Biosystems) with the following settings: $\varsigma$ separation $>6$, angle separation for two cluster SNPs $<1.2 \mathrm{rad}$, median cluster intensity $>2.2$ logs. Genotypes were further reviewed manually and call rates $\geq 90 \%$ in each sample set were required.

Gingival tissue samples and cell culture

For gene expression study, gingival tissue samples were obtained from individuals with healthy gingival conditions and no periodontitis $(n=10)$ as well as from patients with advanced CP $(\mathrm{n}=10)$. All biopsies were collected from healthy patients (age 19-58 years) who underwent third-molar extraction or periodontal surgery and from patients with advanced CP. Healthy gingival conditions were defined as follows: no redness, no swelling, no bleeding on probing, and with periodontal pockets $\leq 3 \mathrm{~mm}$. Patients with advanced CP showed all typical clinical signs of periodontal inflammation (redness, swelling, bleeding on probing) and a periodontal probing depth $\geq 6 \mathrm{~mm}$. For culture of gingival epithelial cells (GECs) $(n=3)$ and human gingival fibroblasts (HGFs) $(n=3)$, gingival epithelial tissue samples were prepared as previously described. ${ }^{40}$ Epithelial cells were cultured in keratinocyte growth medium (KGM) using supplements provided with the medium (PAA, Cölbe, Germany) and 1\% antibiotics (penicillin, streptomycin, amphotericin; PAA), whereas fibroblasts were cultured using Dulbecco's modified Eagle's medium (DMEM; PAA) supplemented with 1\% antibiotics (penicillin, streptomycin, amphotericin; PAA) and 10\% fetal bovine serum (FBS; PAA). Both GECs and HGFs were cultured at $37^{\circ} \mathrm{C}$ in a humidified atmosphere $(5 \%$ carbon dioxide).

\section{Bacterial cell culture and stimulation experiments}

Wild-type Porphyromonas gingivalis strain ATCC 33277 was cultured under anaerobic conditions, whereas Streptococcus gordonii was grown under aerobic conditions as previously described. ${ }^{41} 42$ Bacterial numbers were determined by absorbance measurement using a spectrophotometer (Biochrom AG, Berlin, Germany). To mimic early stages of inflammation and to test

Table 1 Characteristics of the study populations

\begin{tabular}{|c|c|c|c|c|c|c|}
\hline & \multicolumn{3}{|l|}{ Dutch } & \multicolumn{3}{|l|}{ German } \\
\hline & $\begin{array}{l}\text { Aggressive } \\
\text { periodontitis }\end{array}$ & $\begin{array}{l}\text { Chronic } \\
\text { periodontitis }\end{array}$ & Controls & $\begin{array}{l}\text { Aggressive } \\
\text { periodontitis }\end{array}$ & $\begin{array}{l}\text { Chronic } \\
\text { periodontitis }\end{array}$ & Controls \\
\hline \multicolumn{7}{|l|}{ Subject characteristic } \\
\hline Individuals, N (\%) & 159 & 154 & 421 & 301 & 740 & 962 \\
\hline Men & $41(25.8)$ & $56(36.4)$ & $\begin{array}{l}185(43.9) \\
5 \mathrm{~ns}\end{array}$ & $112(37.2)$ & $\begin{array}{l}302(40.8), \\
5 \mathrm{~ns}\end{array}$ & $\begin{array}{l}559(58.1), \\
1 \mathrm{~ns}\end{array}$ \\
\hline Women & $118(74.2)$ & $98(63.6)$ & $231(54.9)$ & $189(62.8)$ & $433(58.5)$ & $402(41.8)$ \\
\hline Mean age (SD) at first diagnosis & $30.4(4.2)$ & ns & - & $29.5(4.7)$ & ns & - \\
\hline Mean age (SD) at examination & $33.8(4.7)$ & $45.2(9.5)$ & $32.3(9.0)$ & $31.4(6.1)$ & $61.2(10.3)$ & $56.9(12.7)$ \\
\hline \multicolumn{7}{|l|}{ Study information } \\
\hline Recruitment period & $2003-2008$ & 1995-2004 & 1995-2008 & $2003-2008$ & $2000-2006$ & $2002-2006$ \\
\hline \multicolumn{7}{|l|}{ Phenotype } \\
\hline Affected teeth, mean (SD) & $5.8(3.9)$ & ns & - & $8.6(6.4)$ & ns & - \\
\hline \multicolumn{7}{|l|}{ Risk factor, N (\%) } \\
\hline Ever smoked & $123(77.4)$ & $128(83.1)$ & $197(46.8)$ & $147(48.8)$ & $487(65.8)$ & $492(51.1)$ \\
\hline \multirow[t]{2}{*}{ Diabetes mellitus } & $1(0.6)$ & $1(0.6)$ & $2(0.2)$ & $3(1.0)$ & $37(5.0)$ & 44 (4.6) \\
\hline & $5 \mathrm{~ns}$ & $1 \mathrm{~ns}$ & 354 & $67 \mathrm{~ns}$ & $5 \mathrm{~ns}$ & 3 ns \\
\hline
\end{tabular}

Values are given as mean (SD) when appropriate. Affection status was based on reported history. Age was reported by the clinicians. Smoking was estimated by self-report of the individuals ns, not specified. 
the potential transcriptional response of these genes, the commensal oral bacterium $S$ gordonii and the pathogenic oral bacterium $P$ gingivalis, commonly present during severe periodontal infection, were chosen to create an in vitro model to mimic periodontal infection of GECs and HGFs. For stimulation experiments, GECs and HGFs were grown to $80 \%$ confluence and then incubated with $P$ gingivalis and $S$ gordonii, respectively, using an amount equivalent to a multiplicity of infection of 100:1, for either $6 \mathrm{~h}$ or $24 \mathrm{~h}$. Experimental groups were: (1) unstimlated GECs and HGFs; (2) control cells (GECs and HGFs) treated with blank bacterial medium for $S$ gordonii not containing bacterial cells; (3) control cells (GECs and HGFs) treated with blank bacterial medium for $P$ gingivalis not containing bacterial cells; (4) stimulation of GECs and HGFs with $S$ gordonii; (5) stimulation of GECs and HGFs with $P$ gingivalis; and (6) pre-incubation of GECs and HGFs with $S$ gordonii followed by medium change and stimulation with $P$ gingivalis. Each stimulation experiment was performed in triplicate, using cells from three different donors.

\section{RNA extraction and PCR conditions}

To extract mRNA from the epithelial and the connective tissue layer separately, biopsies were enzymatically dissected using $3 \mathrm{ml}$ dispase (Cascade Biologics, Paisley, UK) for $6 \mathrm{~h}$ on ice. After separation of gingival biopsies, total RNA was extracted from both epithelium and connective tissue (CT) using the RNeasy Protection Mini Kit (Qiagen, Hilden, Germany) according to the manufacturer's instructions.

Subsequent to in vitro stimulation experiments on GECs and HGFs, total RNA was extracted as described above. The reverse transcription reaction with 500 ng of total RNA was performed using iScript (Bio-Rad, Munich, Germany) following the manufacturer's instructions.

Quantitative analysis of the cDNA was performed using the iCycler (Bio-Rad) and the QuantiFast SYBR Green PCR kit (Qiagen) according to the manufacturer's instructions. PCR reactions were carried out in 96-well plates in a total volume of $25 \mu \mathrm{l}$, including $10 \mathrm{ng}$ of cDNA and $250 \mathrm{nM}$ primers. At the end of each real-time PCR, melting curve analysis was performed to confirm that the amplified product was specific. Gene expression levels in the gingival epithelium and the gingival connective tissue were analysed by normalisation to the gene expression levels in healthy gingival epithelium. All sample values were normalised to the expression of the housekeeping gene glycerylaldehyde-3-dehydrogenase (GAPDH, GeneGlobe primer, Qiagen) and relative gene expression was calculated using the delta-delta Ct (threshold cycle) method. PCR controls were performed using water. Primer sequences are given in supplementary table 1 .

\section{Statistical analysis}

Markers were checked for deviation from Hardy-Weinberg equilibrium (HWE) in controls to a significance level of $\alpha=0.05$ before inclusion into the analysis. We assessed the significance of phenotypic association with single marker alleles and genotypes using $\chi^{2}$ and Fisher's exact tests for $2 \times 2$ and $2 \times 3$ contingency tables, respectively. Logistic regression analysis allowing for covariate adjustment was performed in the $\mathrm{R}$ statistical environment, version 2.8.1. ${ }^{43}$ Significance was assessed by a likelihood ratio test. Values of $\mathrm{p} \leq 0.05$ were considered nominally significant. Akaike's information criterion (AIC) was used to choose the model that best explained the underlying associations. Linkage disequilibrium (LD) measures were calculated and plotted using Haploview. Quantitative real time (qRT)-PCR
(qRT-PCR) data were analysed using the Mann-Whitney Test (SPSS, Version 18, Munich, Germany). The significance level was set at $\mathrm{p} \leq 0.05$.

\section{RESULTS \\ Association study with aggressive periodontitis}

To analyse potential genetic associations within the entire CDKN2BAS region, we selected 51 tagSNPs covering $150 \mathrm{~kb}$. These SNPs were genotyped in our combined population of 159 Dutch generalised and localised AgP patients and 421 Dutch healthy controls. In our previous study on the association of CDKN2BAS with $\mathrm{AgP}^{29}$ we demonstrated that the allele frequencies at this genetic locus were very similar between localised and generalised AgP cases, allowing the pooling of both sub-phenotypes to increase the statistical power for detecting associated variants. In a second step, we validated the significant SNPs in an independent panel of our 301 German patients with generalised or localised AgP and 963 German controls. ${ }^{29}$ In a third step, we subsequently tested the selected tagSNPs in this genetic region for potential associations with chronic periodontitis in a panel of 154 Dutch CP cases, and replicated the significant associations in an independent panel of 740 German CP cases. To increase the statistical power, we used the same panels of Dutch and German controls for the association tests performed with the Dutch and German AgP and CP patients, respectively (table 1 ).

Out of the 51 tagSNPs, eight were found to have a minor allele frequency (MAF) below 0.01 in the Dutch populations. These were excluded from the analysis due to their limited expected statistical power. Five further SNPs were excluded due to deviations from HWE in the Dutch controls $(\mathrm{p}<0.05)$. One SNP, rs564398, had poor genotyping quality (call rate $<0.9$ ) and was excluded from further analyses. In the explorative association study of the Dutch AgP case-control population, four SNPs were nominally significantly associated with AgP before adjustment for the common risk factors of gender, smoking, and diabetes (supplementary table 2). Upon covariate adjustment, seven SNPs were nominally significantly associated (table 2, for genotype and allele frequencies see table 3), with SNP rs3217992 being the most significant (OR 2.53, 95\% CI 1.29 to 5.13; $\mathrm{p}=0.007)$. Two SNPs, rs1360590 and rs11790231, showed associations before and after covariate adjustment (supplementary tables 2 and 3 ).

These seven nominally significantly associated SNPs were then tested for their association in the German AgP population. One SNP, rs10965224, showed significant deviations from HWE in the German controls $(\mathrm{p}<0.05)$ and was excluded from further analyses. Before the covariate adjustment, three of the associations remained significant (rs3217992, rs518394, rs1360590), with SNP rs1360590 being most significantly associated with $\mathrm{p}=0.0005$ (multiplicative genetic model) and an OR of 1.41 (CI $95 \% 1.16$ to 1.72 ) (supplementary table 4 ). Upon covariate adjustment, these three SNPs remained significantly associated, with rs3217992 being most significant with $\mathrm{p}=0.0004$ (table 2, supplementary table 5) and an OR of 1.48 (95\% CI 1.19 to 1.85). After Bonferroni correction for multiple testing, these three SNPs remained significant at the corrected significance threshold of $p \leq 0.0083$ for six independent tests. These three SNPs span a chromosomal region of $38 \mathrm{~kb}$ (NCBI build 36.3) and are located within (rs3217992) or downstream of CDKN2B, but were only in moderate LD to each other in our control population (figure 1). Interestingly, none of the SNPs which tagged the large $\mathrm{LD}$ region at the $5^{\prime}$ end of CDKN2BAS, and which was most significantly associated with $\mathrm{CHD}^{9}{ }^{17-19} 20$ as well as with AgP 
Table 2 Minor allele frequencies (MAFs) and single nucleotide polymorphism (SNP) associations of the significant SNPs in the different populations upon adjustment for covariates

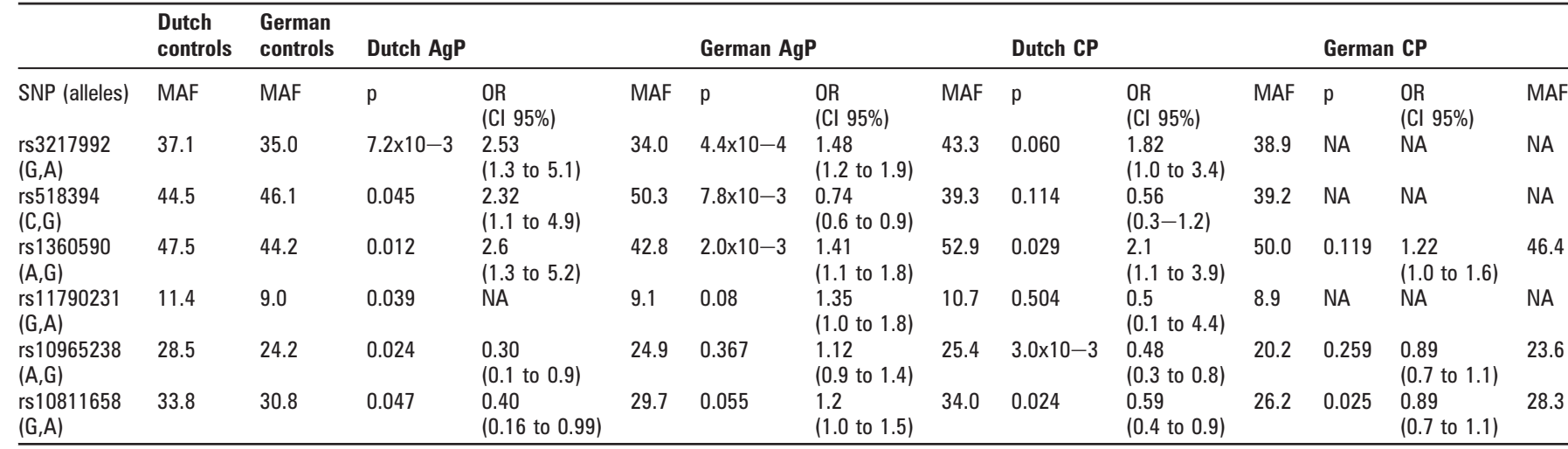

Given are the MAFs, the p values, and the ORs with the $95 \%$ Cls for the different populations. The $p$ values were obtained from a likelihood ratio test and correspond to the genetic model with the lowest AIC value each. Values are given upon adjustment for the covariates smoking, diabetes, and gender for the aggressive periodontitis (AgP) analyses and additionally for age for the chronic periodontitis (CP) analyses, in a logistic regression model.

in our German cases, ${ }^{29}$ was significantly associated with the Dutch AgP patients in this study. The lead SNPs of this region were associated with $\mathrm{CHD}$ and the German AgP cases with a $10 \%$ increase of the rare allele in the homozygotes (eg for SNP rs1333048) and showed similar allele frequencies for the heterozygotes between cases and controls. In contrast, for the Dutch AgP cases we observed an enrichment of $10 \%$ in the heterozygotes but a decrease of $6 \%$ of the rare allele in the homozygotes (supplementary table 6).

\section{Association study with chronic periodontitis}

In the next step, we tested the 37 tagSNPs that had passed the pre-assigned OC for their association with the phenotype chronic periodontitis in the explorative Dutch CP population. Five SNPs were significant before covariate adjustment for gender, age, smoking, and diabetes, with SNP rs10965238 being the most significant (OR $0.57,95 \%$ CI 0.38 to $0.84 ; p=0.004$ ) (supplementary table 7). Upon adjustment, four SNPs remained significant (rs1360590, rs10965224, rs10965238, rs10811658), two of which showed stable associations before and upon covariate adjustment (rs10965238, rs10811658) (figure 1, table 2 and supplementary table 8).

We next tested these three SNPs for their association in the German CP population, again excluding SNP rs10965224 due to its significant deviations from HWE in this control population. Before covariate adjustment, SNP rs10811658 was significantly associated with CP (supplementary table 9). Upon adjustment, this association remained significant in a similar fashion with $\mathrm{p}=0.025$ (OR 0.66, 95\% CI 0.46 to 0.95) (table 2). However, after Bonferroni correction for multiple testing, this association missed significance at the corrected significant threshold of $p<0.0167$ for three independent tests. None of the other SNPs tested in this case-control population showed significant associations upon covariate adjustment (supplementary table 10).

\section{CDKN2BAS, CDKN2A, CDKN2B, and CDK4 mRNA expression in} healthy and inflamed gingival tissues

To show in vivo gene expression of CDKN2BAS, CDKN2A, $C D K N 2 B$, and $C D K 4$, the specific mRNA levels of these genes within the epithelium (EPI) and the connective tissue (CT) of gingival biopsies were analysed. We observed tissue specific expression of all four genes in both EPI and CT. In this explorative study, the expression of CDKN2BAS was significantly higher in healthy CTcompared to healthy EPI ( $p=0.004$, figure $2 \mathrm{~A})$, and this difference remained significant after Bonferroni correction for multiple comparisons. Whereas for CDKN2A no difference in transcript levels was observed between CT and EPI (figure 2B), higher mRNA levels, although not significant in our experiments, were observed for $C D K N 2 B$ in healthy CT compared to healthy EPI $(\mathrm{p}=0.019$, figure $2 \mathrm{C})$. A trend towards a lower gene expression for $C D K 4$, inhibited by $C D K N 2 A$ and $2 B$ in vivo, was noticed in CT compared to EPI (figure 2D).

\section{CDKN2BAS gene expression upregulated in $S$ gordonii pre-treated and $\boldsymbol{P}$ gingivalis stimulated GECs}

We next tested whether the genes were differentially regulated in cultured primary gingival epithelial cells (GECs) when exposed to commensal and/or pathogenic periodontal bacteria. We observed a significant increase of the CDKN2BAS gene expression after $24 \mathrm{~h}$ of stimulation with pathogenic $P$ gingivalis

Table 3 Genotypes and frequencies of the significant single nucleotide polymorphisms (SNPs) in the different populations

\begin{tabular}{|c|c|c|c|c|c|c|c|c|c|c|c|c|c|c|c|c|c|c|}
\hline \multirow[b]{2}{*}{ SNP (alleles) } & \multicolumn{3}{|c|}{ Dutch controls } & \multicolumn{3}{|c|}{ German controls } & \multicolumn{3}{|c|}{$\begin{array}{l}\text { Dutch aggressive } \\
\text { periodontitis }(\mathrm{AgP})\end{array}$} & \multicolumn{3}{|c|}{ German AgP } & \multicolumn{3}{|c|}{$\begin{array}{l}\text { Dutch chronic } \\
\text { periodontitis (CP) }\end{array}$} & \multicolumn{3}{|c|}{ German CP } \\
\hline & $11(\%)$ & $12(\%)$ & $22(\%)$ & $11(\%)$ & $12(\%)$ & $22(\%)$ & $11(\%)$ & $12(\%)$ & $22(\%)$ & $11(\%)$ & $12(\%)$ & $22(\%)$ & $11(\%)$ & $12(\%)$ & $22(\%)$ & $11(\%)$ & $12(\%)$ & $22(\%)$ \\
\hline $\begin{array}{l}\text { rs3217992 } \\
(G, A)\end{array}$ & $\begin{array}{l}171 \\
(41.1)\end{array}$ & $\begin{array}{l}182 \\
(43.6)\end{array}$ & $\begin{array}{l}64 \\
(15.3)\end{array}$ & $\begin{array}{l}281 \\
(42.5)\end{array}$ & $\begin{array}{l}298 \\
(45.0)\end{array}$ & $\begin{array}{l}83 \\
(12.5)\end{array}$ & $\begin{array}{l}66 \\
(41.5)\end{array}$ & $\begin{array}{l}78 \\
(49.1)\end{array}$ & $\begin{array}{l}15 \\
(9.4)\end{array}$ & $\begin{array}{l}96 \\
(32.3)\end{array}$ & $\begin{array}{l}145 \\
(48.8)\end{array}$ & $\begin{array}{l}56 \\
(18.9)\end{array}$ & $\begin{array}{l}60 \\
(39.2)\end{array}$ & $\begin{array}{l}67 \\
(43.8)\end{array}$ & $\begin{array}{l}26 \\
(17.0)\end{array}$ & NA & NA & NA \\
\hline $\begin{array}{l}\text { rs518394 } \\
(\mathrm{C}, \mathrm{G})\end{array}$ & $\begin{array}{l}132 \\
(31.5)\end{array}$ & $\begin{array}{l}201 \\
(48.0)\end{array}$ & $\begin{array}{l}86 \\
(20.5)\end{array}$ & $\begin{array}{l}197 \\
(29.7)\end{array}$ & $\begin{array}{l}321 \\
(48.4)\end{array}$ & $\begin{array}{l}145 \\
(21.9)\end{array}$ & $\begin{array}{l}38 \\
(23.9)\end{array}$ & $\begin{array}{l}82 \\
(51.6)\end{array}$ & $\begin{array}{l}39 \\
(24.5)\end{array}$ & $\begin{array}{l}113 \\
(37.7)\end{array}$ & $\begin{array}{l}138 \\
(46.0)\end{array}$ & $\begin{array}{l}49 \\
(16.3)\end{array}$ & $\begin{array}{l}60 \\
(39.3)\end{array}$ & $\begin{array}{l}66 \\
(43.1)\end{array}$ & $\begin{array}{l}27 \\
(17.6)\end{array}$ & NA & NA & NA \\
\hline $\begin{array}{l}\text { rs1360590 } \\
(A, G)\end{array}$ & $\begin{array}{l}122 \\
(29.0)\end{array}$ & $\begin{array}{l}198 \\
(47.0)\end{array}$ & $\begin{array}{l}101 \\
(24.0)\end{array}$ & $\begin{array}{l}207 \\
(31.2)\end{array}$ & $\begin{array}{l}327 \\
(49.2)\end{array}$ & $\begin{array}{l}130 \\
(19.6)\end{array}$ & $\begin{array}{l}48 \\
(30.2)\end{array}$ & $\begin{array}{l}86 \\
(54.1)\end{array}$ & $\begin{array}{l}25 \\
(15.7)\end{array}$ & $\begin{array}{l}64 \\
(21.4)\end{array}$ & $\begin{array}{l}154 \\
(51.5)\end{array}$ & $\begin{array}{l}81 \\
(27.1)\end{array}$ & $\begin{array}{l}41 \\
(26.6)\end{array}$ & $\begin{array}{l}72 \\
(46.8)\end{array}$ & $\begin{array}{l}41 \\
(26.6)\end{array}$ & $\begin{array}{l}219 \\
(29.7)\end{array}$ & $\begin{array}{l}352 \\
(47.8)\end{array}$ & $\begin{array}{l}166 \\
(22.5)\end{array}$ \\
\hline $\begin{array}{l}\text { rs11790231 } \\
(G, A)\end{array}$ & $\begin{array}{l}330 \\
(78.6)\end{array}$ & $\begin{array}{l}84 \\
(20.0)\end{array}$ & $\begin{array}{l}6 \\
(1.4)\end{array}$ & $\begin{array}{l}551 \\
(83.2)\end{array}$ & $\begin{array}{l}104 \\
(15.7)\end{array}$ & $\begin{array}{l}7 \\
(1.1)\end{array}$ & $\begin{array}{l}130 \\
(81.8)\end{array}$ & $\begin{array}{l}29 \\
(18.2)\end{array}$ & $\begin{array}{l}0 \\
(0.0)\end{array}$ & $\begin{array}{l}238 \\
(79.9)\end{array}$ & $\begin{array}{l}56 \\
(18.8)\end{array}$ & $\begin{array}{l}4 \\
(1.3)\end{array}$ & $\begin{array}{l}129 \\
(84.3)\end{array}$ & $\begin{array}{l}21 \\
(13.7)\end{array}$ & $\begin{array}{l}3 \\
(2.0)\end{array}$ & NA & NA & NA \\
\hline $\begin{array}{l}\text { rs10965238 } \\
(A, G)\end{array}$ & $\begin{array}{l}202 \\
(51.4)\end{array}$ & $\begin{array}{l}158 \\
(40.2)\end{array}$ & $\begin{array}{l}33 \\
(8.4)\end{array}$ & $\begin{array}{l}363 \\
(58.4)\end{array}$ & $\begin{array}{l}216 \\
(34.8)\end{array}$ & $\begin{array}{l}42 \\
(6.8)\end{array}$ & $\begin{array}{l}86 \\
(56.2)\end{array}$ & $\begin{array}{l}58 \\
(37.9)\end{array}$ & $\begin{array}{l}9 \\
(5.9)\end{array}$ & $\begin{array}{l}160 \\
(56.2)\end{array}$ & $\begin{array}{l}105 \\
(36.8)\end{array}$ & $\begin{array}{l}20 \\
(7.0)\end{array}$ & $\begin{array}{l}97 \\
(65.1)\end{array}$ & $\begin{array}{l}44 \\
(29.5)\end{array}$ & $\begin{array}{l}8 \\
(5.4)\end{array}$ & $\begin{array}{l}420 \\
(59.9)\end{array}$ & $\begin{array}{l}232 \\
(33.0)\end{array}$ & $\begin{array}{l}50 \\
(7.1)\end{array}$ \\
\hline $\begin{array}{l}\text { rs10811658 } \\
(G, A)\end{array}$ & $\begin{array}{l}181 \\
(43.2)\end{array}$ & $\begin{array}{l}193 \\
(46.1)\end{array}$ & $\begin{array}{l}45 \\
(10.7)\end{array}$ & $\begin{array}{l}324 \\
(49.1)\end{array}$ & $\begin{array}{l}266 \\
(40.3)\end{array}$ & $\begin{array}{l}70 \\
(10.6)\end{array}$ & $\begin{array}{l}77 \\
(48.8)\end{array}$ & $\begin{array}{l}68 \\
(43.0)\end{array}$ & $\begin{array}{l}13 \\
(8.2)\end{array}$ & $\begin{array}{l}130 \\
(43.4)\end{array}$ & $\begin{array}{l}135 \\
(45.2)\end{array}$ & $\begin{array}{l}34 \\
(11.4)\end{array}$ & $\begin{array}{l}84 \\
(54.9)\end{array}$ & $\begin{array}{l}58 \\
(37.9)\end{array}$ & $\begin{array}{l}11 \\
(7.2)\end{array}$ & $\begin{array}{l}374 \\
(50.7)\end{array}$ & $\begin{array}{l}310 \\
(42.1)\end{array}$ & $\begin{array}{l}53 \\
(7.2)\end{array}$ \\
\hline
\end{tabular}



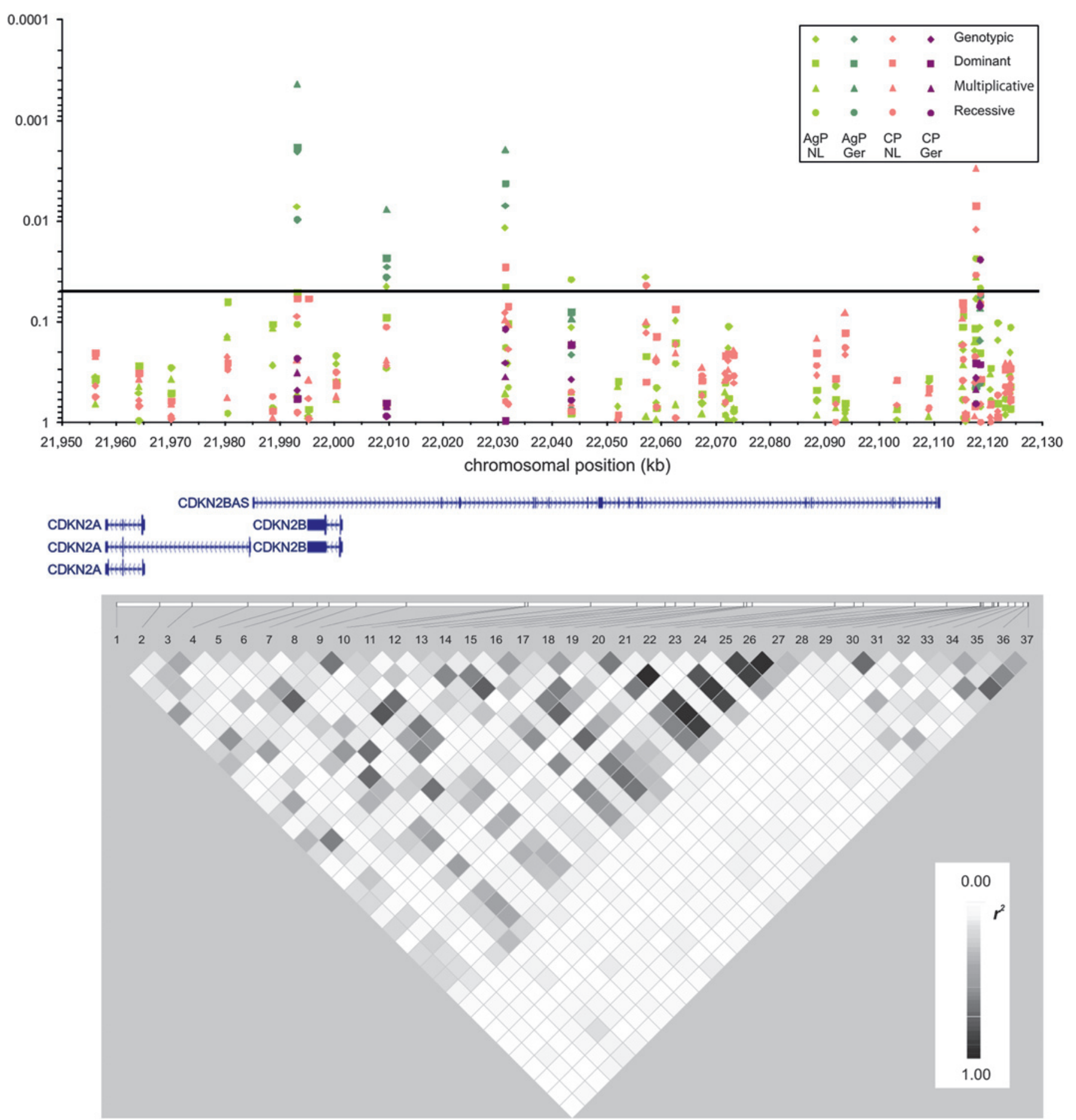

Figure 1 Genetic region of CDKN2BAS, The top diagram shows the nominal $-\log _{10} p$ under the assumption of the different genetic models of those single nucleotide polymorphisms (SNPs) that passed the preassigned quality criteria. The $-\log _{10} p$ values are plotted as a function of the genomic htSNP position (NCBI build 36). The bottom panel shows pairwise linkage disequilibrium (LD) in the controls using metric $\mathrm{r}^{2}$. AgP, aggressive periodontitis; CP, chronic periodontitis; Dominant, dominant model; Genotypic, genotypic model; Ger, Germany; NL, Netherlands; Recessive, recessive model; bp, base pairs; 1, rs3731257; 2, rs3731239; 3, rs2811709; 4, rs7036656; 5, rs3218009; 6, rs3217992; 7, rs3217986; 8, rs495490; 9, rs518394; 10, rs1360590; 11, rs17694493; 12, rs11790231; 13, rs1011970; 14, rs10965224; 15, rs16905599; 16, rs10757270; 17, rs1412832; 18, rs10965227; 19, rs10965228; 20, rs1333040; 21, rs2891168; 22, rs10125231; 23, rs1333042; 24, rs13301964; 25, rs1333045; 26, rs1333048; 27, rs1333049; 28, rs1333050; 29, rs10757281; 30, rs10965238; 31, rs10811658; 32, rs12347779; 33, rs10965245; 34, rs2891169; 35, rs7045889; 36, rs10811661; 37, rs10757283.

in commensal $S$ gordonii pre-treated GECs with $\mathrm{p}=0.003$ (fourfold increase), and this difference remained significant after Bonferroni correction for multiple comparisons (figure $3 \mathrm{~A}$ ). In the same experiments, CDKN2A mRNA levels were significantly reduced after $24 \mathrm{~h}$ of stimulation with pathogenic $P$ gingivalis in commensal $S$ gordonii pre-treated GECs with $\mathrm{p}=0.004$, if compared to unstimulated GECs (figure $3 \mathrm{~B}$ ). A similar reduction, not significant in our experiments, was observed between $6 \mathrm{~h}$ and $24 \mathrm{~h}$ of $P$ gingivalis stimulation after $S$ gordonii pre-treatment. For $C D K N 2 B$, we observed a trend towards reduced 
Figure 2 mRNA levels of CDKN2BAS, CDKN2A, CDKN2B and CDK4 in healthy and inflamed gingival epithelium and connective tissue. (A) CDKN2BAS transcript levels were higher in healthy connective tissue compared to healthy gingival epithelium $(p=0.004)$. $(B-D)$ CDKN2A, CDKN2B, and CDK4 mRNA showed no statistically significant differences in transcript levels between healthy or inflamed epithelial and connective gingival tissues. Each box plot represents results derived from 10 different subjects. CT, connective tissue; EPI, gingival epithelial tissue; $H$, healthy; I, inflamed.
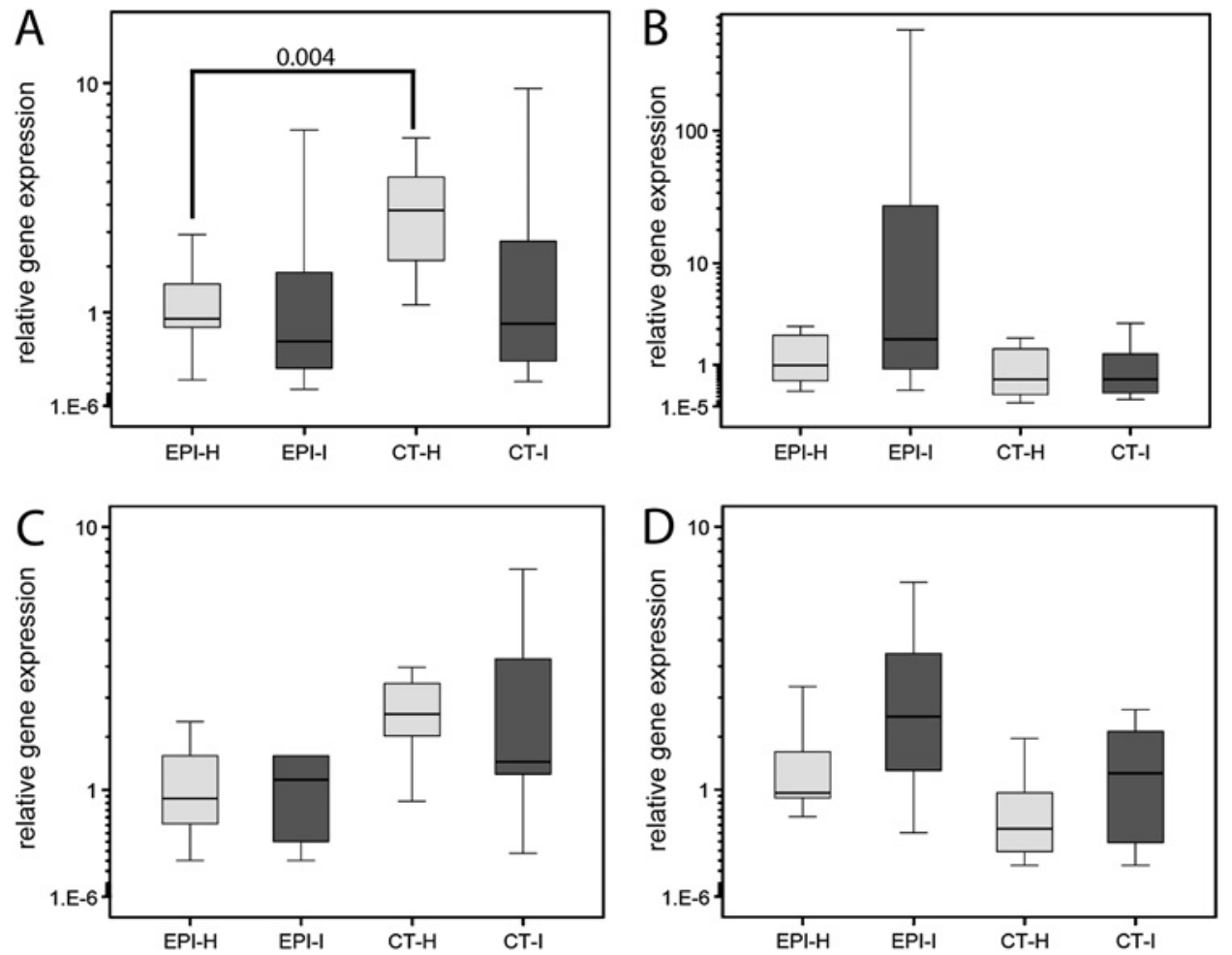

transcript levels after $24 \mathrm{~h}$ incubation with $P$ gingivalis in $S$ gordonii pre-treated GECs (figure $3 \mathrm{C}$ ). CDK4 expression was significantly reduced after $24 \mathrm{~h}$ of stimulation with pathogenic $P$ gingivalis in commensal $S$ gordonii pre-treated GECs compared to unstimulted GECs $(p=0.004$, figure $3 D)$. A similar reduction, not significant in our experiments, was observed between $6 \mathrm{~h}$ and $24 \mathrm{~h} P$ gingivalis stimulation after $S$ gordonii pre-treatment.

\section{CDKN2BAS gene expression upregulated in $\boldsymbol{P}$ gingivalis stimulated HGFs}

In the second gingival cell population of gingival fibroblasts (HGFs), 24 h stimulation with $P$ gingivalis alone and after pretreatment with $S$ gordonii led to significant CDKN2BAS mRNA upregulation after $24 \mathrm{~h}$ with $\mathrm{p}=0.004$ and $\mathrm{p}=0.003$ (25-fold), respectively, and remained significant after Bonferroni correction for multiple comparisons (figure 4A). CDKN2A mRNA levels were significantly reduced ( $\mathrm{p}=0.001)$ after $24 \mathrm{~h}$ stimulation with $P$ gingivalis after pre-treatment with $S$ gordonii (figure 4B). No clear trend in transcript levels could be observed for $C D K N 2 B$ and CDK4 in any experimental condition (figure 4C,D).

\section{DISCUSSION}

The aim of this study was to identify genetic risk alleles within the genetic region of CDKN2BAS, CDKN2A and CDKN2B, which are shared by different European populations of the periodontal disease phenotypes AgP and CP. We showed three SNPs to be significantly associated with two AgP populations of different ancestry (rs3217992, rs518394, and rs1360590), and confirmed these associations to be independent of the traditional risk factors of smoking, diabetes and gender. These SNPs were located within or closely downstream of the coding region of $C D K N 2 B$, but no SNP could be identified as a lead SNP that fully explained the associations with periodontitis.

Interestingly, we could not replicate our previous finding of a statistically significant association of the large CHD associated $\mathrm{LD}$ region at the $5^{\prime}$ end of CDKN2BAS with the Dutch AgP patients. As described earlier, ${ }^{29}$ in the German AgP cases the frequency of the rare allele of the lead SNP from this study, rs1333048, was 10\% higher compared to the controls and the frequencies for the heterozygotes was similar to the controls. This observation was similarly reported by association studies on CHD. ${ }^{9}$ Interestingly, in the present study, the Dutch AgP cases showed an enrichment of $10 \%$ in the heterozygotes for this SNP, but the homozygotes of the risk allele were decreased. We ruled out potential genotyping errors of this assay by verifying the genotypes of SNP rs1333048 with two independent technologies, which gave identical results. Increased heterozygotes in the Dutch AgP cases were similarly observed for the significantly associated SNPs rs1360590, rs3217992, and rs518394. In contrast to the observation in the Dutch AgP patients, the Dutch CP cases, and to a lesser extent the German CP cases, showed a tendency towards an increased frequency of homozygosity for the risk allele, with a frequency of heterozygotes similar to the controls. A possible speculative explanation for the observed increase of heterozygous Dutch AgP patients at this particular locus could be the presence of duplicated structural variations of this element in these cases, which were not present in the Dutch controls and CP cases.

The discovered associations, which were shared between different populations, did not follow a particular model of inheritance (genotypic, dominant, recessive or multiplicative). However, this observation is rather typical for association studies of our sample sizes, where it is practically impossible to assess confidently which model fits the data best, and where the specific models might reflect noise rather than a specific fit to a model. A future meta-analysis with data across many different datasets will improve this situation and might help to identify the best-fit model. ${ }^{44}$ The genetic effects that were estimated for the associated SNPs also partly differed between the populations. Corresponding to the variations in the genetic best-fit models, the genetic effects are statistical estimates which are liable to estimation errors, which are mostly attributed to effects of individual random samples which constitute 
Figure 3 mRNA levels of CDKN2BAS, $C D K N 2 A, C D K N 2 B$, and $C D K 4$ in gingival epidermal cells after stimulation with Streptococcus gordonii and Porphyromonas gingivalis. (A) After $24 \mathrm{~h}$ of bacterial infection, CDKN2BAS mRNA expression was significantly increased upon $24 \mathrm{~h} P$ gingivalis stimulation of $S$ gordonii pre-treated gingival epithelial cells (GECs) compared to $6 \mathrm{~h}$ of stimulation $(\mathrm{p}=0.003)$. (B) CDKN2A gene expression was significantly reduced in response to $24 \mathrm{~h}$ of $P$ gingivalis stimulation after $S$ gordonii pre-treatment compared to unstimulated GECs $(p=0.004)$. A similar reduction, not significant in our experiments, was observed between $6 \mathrm{~h}$ and $24 \mathrm{~h}$ of $P$ gingivalis stimulation after $S$ gordonii pre-treatment. (C) For CDKN2B, no significant differences in mRNA transcript levels were observed in GECs upon bacterial stimulation. (D) CDK4 mRNA levels were significantly reduced after $S$ gordonii pre-treated followed by $24 \mathrm{~h}$ of stimulation with $P$ gingivalis compared to unstimulated GECs $(p=0.004)$. A similar reduction, not significant in our experiments, was observed between $6 \mathrm{~h}$ and $24 \mathrm{~h}$ of $P$ gingivalis stimulation after $S$ gordonii pre-treatment. Each box plot represents values derived from nine independent experiments and cells from three different donors were tested. $\mathrm{C}$, unstimulated cells; GEC, gingival epidermal cells; MPG, blank medium for $P$ gingivalis; $M S G$, blank medium for $S$ gordonii; PG, $P$ gingivalis; SG, $S$ gordonii; SG-PG, pre-treatment with $S$ gordonii for $1 \mathrm{~h}$ followed by $P$ gingivalis stimulation for $6 \mathrm{~h}$ and $24 \mathrm{~h}$.
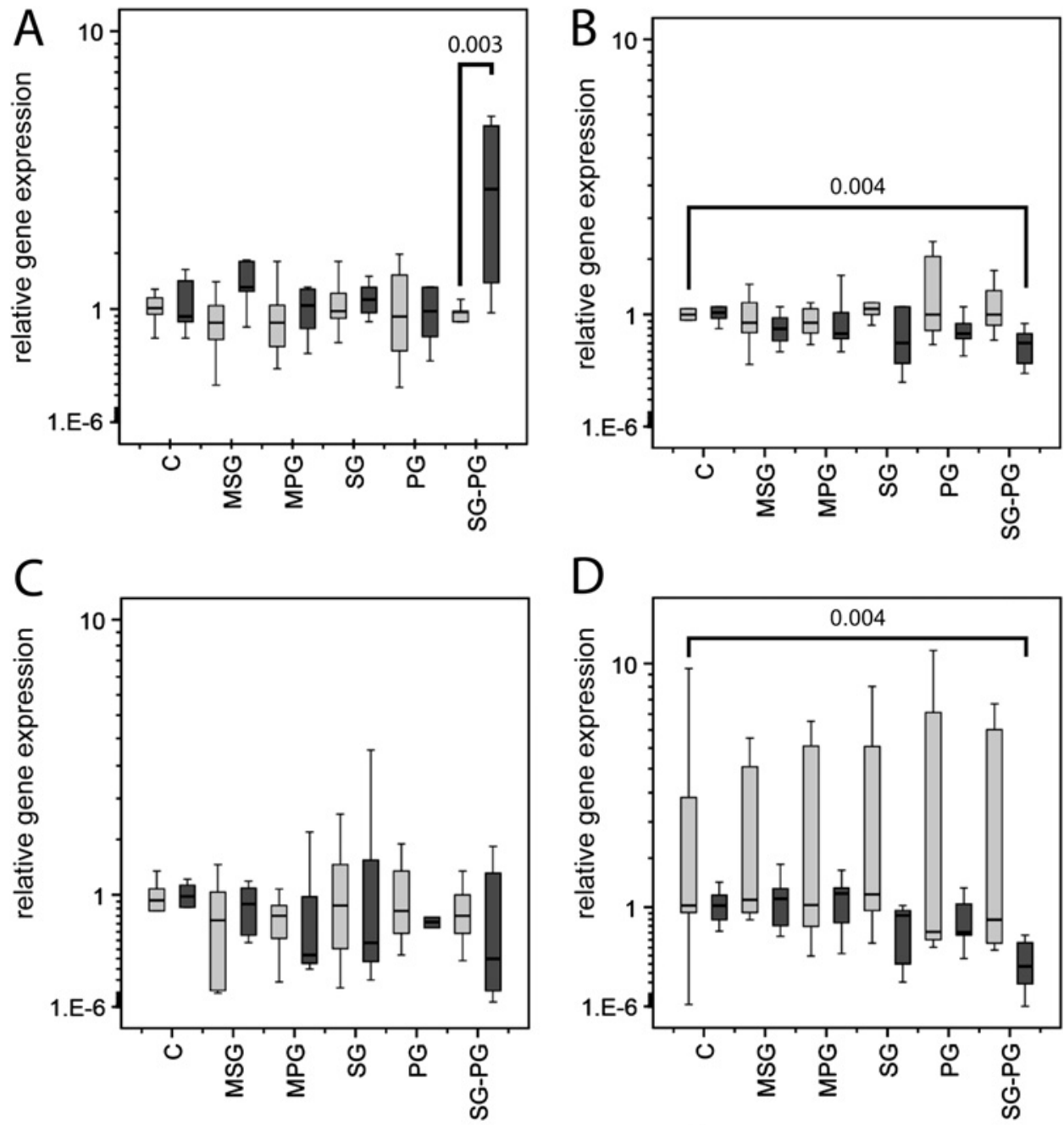

D

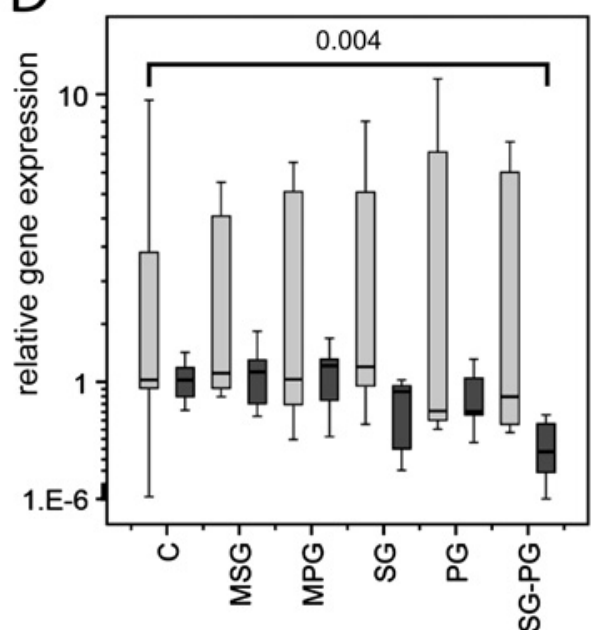

\section{Time}

$6 \mathrm{~h} \square 24 \mathrm{~h}$ each population analysed. If the causative variant has not been identified, the observed SNP associations reflect the genetic effect of the causative variant through shared $\mathrm{LD}$, which can vary between populations of different ancestry.

Although this broad validation study of the previously reported association of CDKN2BAS with periodontitis adds further evidence that variants at this locus increase the risk of periodontitis in individuals of Northern European origin, it is evident from the number and distribution of the significant SNP associations-which were observed in our current and our previous study, and similarly in other larger studies on $\mathrm{CHD}^{9} 33$ that the causative variant(s) and the related disease mechanisms remain to be identified. Additionally, we observed nominally significant SNP associations in the CP populations. Considering that individuals who experienced early development of periodontitis are likely to have inherited a major genetic disease variant, it is conceivable that in larger populations of the rather moderate phenotype chronic periodontitis, these SNPs may show their significance for CP as well as they did for the more severe AgP phenotype. To clarify this, replication experiments in further large populations of CP would be desirable.

The risk of periodontitis related to this locus may vary among different ethnic groups, which is suggested by frequency variations of the disease associated rs1333048-C allele from $21 \%$ in Yoruba to $51 \%$ in European and Japanese in HapMap. To identify the true causative variant(s), that may also be different between various ethnic groups, further genetic exploration of this genetic region in much larger analysis populations, including large analysis populations of various ethnic backgrounds, is necessary. A technical limitation of our study was the failure to genotype 16 of the selected tagSNPs in all populations, especially when the moderate $\mathrm{LD}$ across most of the genetic region of CDKN2BAS is considered. Here, an LD region harbouring the potential true variant(s) might have been missed. Future studies that will apply deep resequencing of cases carrying the associated variants across CDKN2BAS will obtain the full spectrum of variation in this region, and will be able to identify the causal variant(s) that affect the genetic risk.

In the second part of our study, we analysed the expression patterns of CDKN2BAS, CDKN2A, CDKN2B, and CDK4 in healthy and inflamed gingiva, and assessed if these genes were regulated by a signal transduction cascade sensitive to bacterial infection. All analysed genes were expressed in the gingiva, with $C D K N 2 B A S$ and $C D K N 2 B$ both showing the highest mRNA levels of the analysed genes in CT. We did not observe different transcript levels between healthy or inflamed gingival tissues. This could indicate that these genes are not regulated by the 
Figure 4 mRNA levels of CDKN2BAS, CDKN2A, CDKN2B and CDK4 in human gingival fibroblasts after stimulation with Streptococcus gordonii and Porphyromonas gingivalis. (A) CDKN2BAS mRNA levels were significantly increased in non-S gordonii pre-treated $(\mathrm{p}=0.004)$ and $S$ gordonii pre-treated human gingival fibroblasts (HGFs) ( $p=0.003$ ) after $24 \mathrm{~h}$ of stimulation with $P$ gingivalis. (B) CDKN2A mRNA levels were significantly reduced in $S$ gordonii pretreated and $24 \mathrm{~h} P$ gingivalis stimulated HGFs compared to unstimulated HGFs $(p<0.001)$. (C, D) No significant differences of mRNA levels were observed for CDKN2B and CDK4 mRNA levels in either condition. Each box plot represents values derived from nine independent experiments and cells from three different donors were tested. C, unstimulated cells; HGF, human gingival fibroblasts; $M P G$, blank medium for $P$ gingivalis; MSG, blank medium for $S$ gordonii; PG, $P$ gingivalis; SG, $S$ gordonii; SG-PG, pre-treatment with $S$ gordonii for $1 \mathrm{~h}$ followed by $P$ gingivalis stimulation for $6 \mathrm{~h}$ and $24 \mathrm{~h}$.
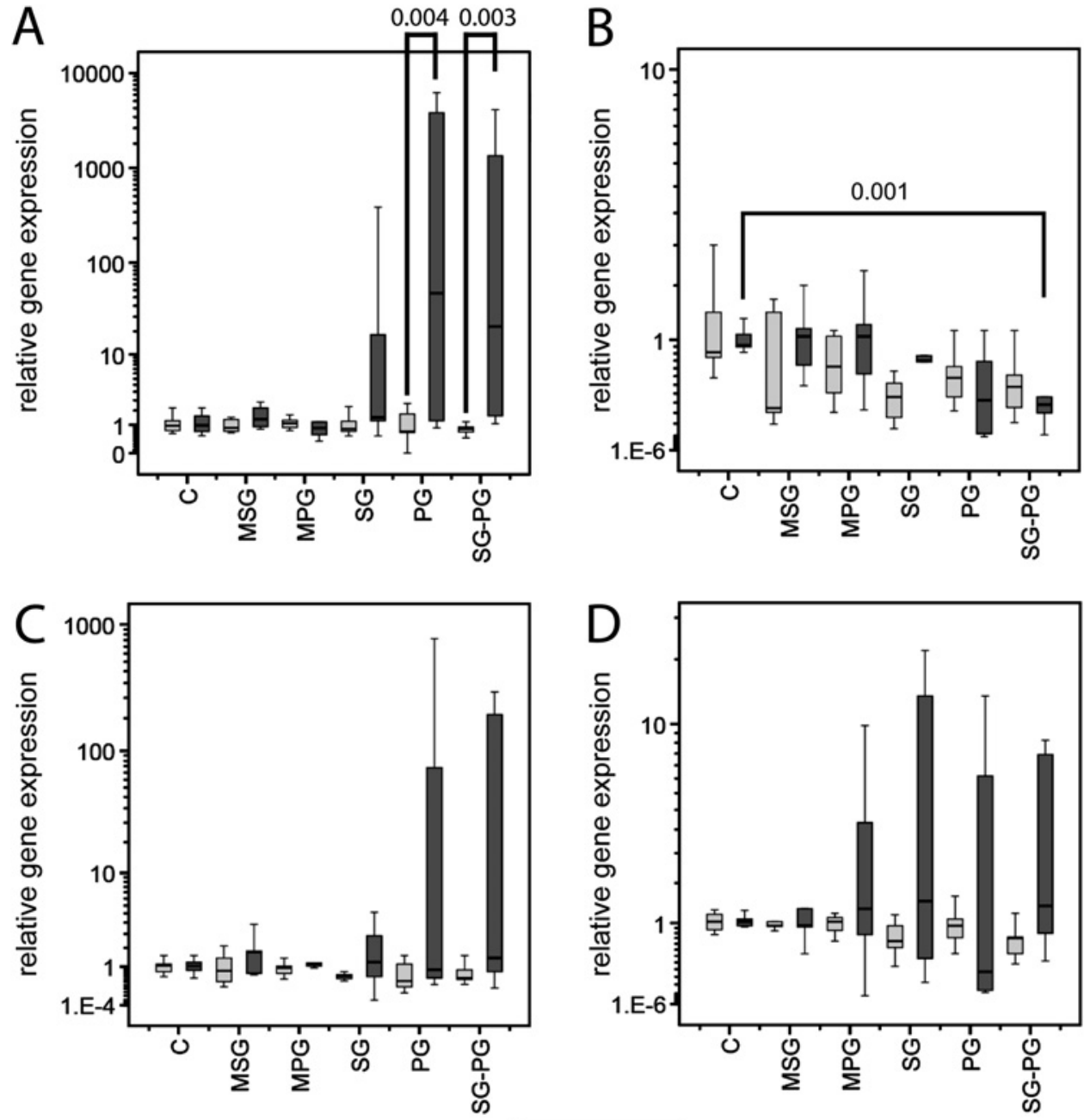

inflammatory status of the gingiva. However, although healthy gingival samples were taken from areas with no clinical signs of inflammation, surfaces of the oral cavity are constantly exposed to both commensal and pathogenic microorganisms. Therefore, it can be speculated that the clinically healthy gingiva is subjected to challenges similar to those of the early stages of infection. Likewise, gingival samples with periodontitis represent a tissue where constant infection and chronic inflammation occurred over years, and short term responses on the transcriptional level are most likely missed in inflamed gingival tissue samples. Here, an experimental setting that precisely controls for pathogenic infection might be a better way to assess specific transcriptional responses.

Because the functional variant(s) are as yet unknown for both periodontitis as well as for $\mathrm{CHD}$, we did not aim to study the putative biological effects of the associated variants. Thus, we did not distinguish between the allelic background in our cell cultures, but studied the transcription pattern of the selected genes in response to bacterial infection. We observed that after $24 \mathrm{~h}$ of stimulation of healthy HGFs and GECs with the pathogenic bacterium $P$ gingivalis, CDKN2BAS was significantly upregulated compared to the unstimulated controls. This realtime response of $C D K N 2 B A S$ gene activity to a specific pathogenic inflammatory trigger indicates that CDKN2BAS is subjected to pathogen sensitive transcriptional regulation. Furthermore, the clear response after $24 \mathrm{~h}$ of stimulation, but the absence of elevated transcript levels after $6 \mathrm{~h}$ of stimulation, suggests that CDKN2BAS may be located at a downstream position of a putative pathogen sensitive signalling cascade. We further observed a minor but significant downregulation of CDKN2A after $24 \mathrm{~h}$ of bacterial stimulation in both gingival epidermal tissue and gingival fibroblasts. These large quantitative differences in CDKN2BAS and CDKN2A transcript levels in response to $24 \mathrm{~h}$ bacterial stimulation possibly indicate that $C D K N 2 A$, unlike CDKN2BAS, is not directly regulated by bacterial infection on the transcriptional level, but at a later stage of this signal transduction cascade.

Our observations were in accordance with a very recent study on CDKN2BAS function which showed that CDKN2BAS transcripts negatively regulate $C D K N 2 A$ expression. ${ }^{31}$ This recent study detected that CDKN2BAS transcript initiates in prostate cancer tissues at a start site several hundred bases upstream of the previously reported start site. An antisense construct designed to target this newly identified transcript caused a pronounced increase in the expression of $C D K N 2 A$, but had a much less profound effect on $C D K N 2 B .{ }^{31}$ In conjunction with various other experiments, the authors concluded that the transcript encoded upstream of the previously reported start site of CDKN2BAS controls CDKN2A silencing by cis recruitment of polycomb group complex proteins, and in addition functions as an architectural matrix to retain these proteins at the target site. Interestingly, a recent study, which performed genome wide expression profiling 
in healthy individuals who were homozygous for the common and the rare allele of rs1333049, showed that the nature of the genes and pathways linked to CDKN2BAS transcript levels comprised genes which control cellular proliferation. ${ }^{30}$ These studies did not functionally analyse exons $1-19$, but a second antisense construct designed to target exon 3 silenced CDKN2A to a much lesser extent than the antisense construct upstream of exon $1 .{ }^{31}$ Although the function of this transcript was not studied in detail, it indicates that different CDKN2BAS transcripts may have different functions. Currently, 10 alternative spliced variants were reported in different tissues as diverse as lung, brain, heart, vascular epithelial tissues, testis, and blood. ${ }^{3045} 46$ They may have specific functions in their tissue specific context, additional or alternative to the observed negative control of CDKN2A. Two studies measured the expression of CDKN2BAS spliced transcript NR_003529, spanning exons 17 to 18, and found slightly decreased expression which was associated with the risk allele in healthy individuals. 3032

A study on individuals with clinically suspected CHD revealed that NR_003529 expression was significantly increased in individuals with atherosclerotic plaque burden, and correlated ANRIL transcript levels with severity of atherosclerosis. ${ }^{47}$ Our primers for the quantification of CDKN2BAS transcript levels were designed to detect NR_003529 transcripts, and we found $N R \_003529$ upregulation by bacterial infection. The correlation of $C D K N 2 B A S$ expression with bacterial infection and increased $C D K N 2 B A S$ expression in individuals with atherosclerotic plaque burden add to the theory of inflammatory components in the pathophysiology of $\mathrm{CHD}$. Considering the recent finding on the ability of the $5^{\prime}$ transcript of CDKN2BAS to recruit and retain regulatory proteins, the functions of the proximal and considerably long sequences of CDKN2BAS might well have a similar mechanistic function, but may also be able to act in trans.

Theories concerning the actual disease mechanism that is mediated by the causative risk variants of CDKN2BAS remain speculative, as the exact nature of the causative variants and the target proteins or genes await elucidation. They possibly differ between $\mathrm{CHD}$ and periodontitis. Here, we present findings which link the pathogenicity of $P$ gingivalis and its contribution to rapid periodontal degradation to a biological mechanism that is mediated by CDKN2BAS, that may directly act in cis on the negative regulation of $C D K N 2 A$ and the downstream lying genes of the $C D K N 2 A$ regulation cascade; or additionally, may act on other, as yet unknown, trans-acting regulatory proteins with unidentified genetic targets. Taking into consideration the correlation of increased ANRIL transcript levels with the severity of atherosclerosis, ${ }^{52}$ this link might also join bacterial infection to atherosclerotic plaque burden by a potentially regulatory mechanism that is mediated by ANRIL transcription.

Funding This study was supported by a research grant from the "Research Center for Inflammation Medicine" of the Medical Faculty, Christian-Albrechts-University, University Medical Center Schleswig-Holstein, Campus Kiel, (Arne S Schaefer, Gesa M Richter), by the German Ministry of Education and Research (BMBF) through a National Genome Research Network (NGFN) grant (Michael Nothnagel, 01GS0809), by grants of the German Research Foundation (DFG) (KF0208) (TP3: Arne S Schaefer, Gesa M Richter, Søren Jepsen) (TP2: Henrik Dommisch, Markus Reinartz, Søren Jepsen), by the BMBF through the POPGEN biobank project (01GR0468), by a grant from BONFOR of the Medical Faculty, University of Bonn (Søren Jepsen), and a grant from the ARPA Research Foundation (Birte Grössner-Schreiber, Søren Jepsen), Regensburg, Germany.

\section{Competing interests None.}

Patient consent Obtained.

Ethics approval This study was conducted with the approval of the Medical Ethical Committee, Universities of Bonn, Dresden, Kiel and Munich, Germany, and Medical
Ethical Committee, Academic Medical Center, University of Amsterdam, the Netherlands.

Provenance and peer review Not commissioned; externally peer reviewed.

\section{REFERENCES}

1. Lopez AD, Mathers CD, Ezzati M, Jamison DT, Murray CJ. Global and regional burden of disease and risk factors, 2001: systematic analysis of population health data. Lancet 2006;367:1747-57

2. Thom T, Haase N, Rosamond W, Howard VJ, Rumsfeld J, Manolio T, Zheng ZJ, Flegal K, O'Donnell C, Kittner S, Lloyd-Jones D, Goff DC Jr, Hong Y, Adams R, Friday G, Furie K, Gorelick P, Kissela B, Marler J, Meigs J, Roger V, Sidney S, Sorlie P, Steinberger J, Wasserthiel-Smoller S, Wilson M, Wolf P; American Heart Association Statistics Committee and Stroke Statistics Subcommittee. Heart disease and stroke statistics-2006 update: a report from the American Heart Association Statistics Committee and Stroke Statistics Subcommittee. Circulation 2006;113: e85-151.

3. Bahekar AA, Singh S, Saha S, Molnar J, Arora R. The prevalence and incidence of coronary heart disease is significantly increased in periodontitis: a meta-analysis. $A m$ Heart $J$ 2007; 154:830-7.

4. Dietrich T, Jimenez M, Krall Kaye EA, Vokonas PS, Garcia RI. Age-dependent associations between chronic periodontitis/edentulism and risk of coronary heart disease. Circulation 2008:117:1668-74.

5. Austin MA, King MC, Bawol RD, Hulley SB, Friedman GD. Risk factors for coronary heart disease in adult female twins. Genetic heritability and shared environmental influences. Am J Epidemiol 1987:125:308-18.

6. Feinleib M, Garrison RJ, Fabsitz R, Christian JC, Hrubec Z, Borhani NO, Kannel WB, Rosenman R, Schwartz JT, Wagner JO. The NHLBI twin study of cardiovascular disease risk factors: methodology and summary of results. Am J Epidemiol 1977; 106:284-5

7. Heller DA, de Faire U, Pedersen NL, Dahlén G, McClearn GE. Genetic and environmental influences on serum lipid levels in twins. $N$ Engl J Med 1993;328:1150-6.

8. Hunt SC, Hasstedt SJ, Kuida H, Stults BM, Hopkins PN, Williams RR. Genetic heritability and common environmental components of resting and stressed blood pressures, lipids, and body mass index in Utah pedigrees and twins. Am J Epidemiol 1989;129:625-38.

9. Schunkert H, Gotz A, Braund P, McGinnis R, Tregouet DA, Mangino M, LinselNitschke P, Cambien F, Hengstenberg C, Stark K, Blankenberg S, Tiret L, Ducimetiere P. Keniry A Ghori MJ, Schreiber S, El Mokhtari NE, Hall AS, Dixon RJ, Goodall AH, Liptau H, Pollard H, Schwarz DF, Hothorn LA, Wichmann HE, König IR, Fischer M, Meisinger C, Ouwehand W, Deloukas P, Thompson JR, Erdmann J, Ziegler A, Samani NJ. Cardiogenics Consortium. Repeated replication and a prospective meta-analysis of the association between chromosome 9p21.3 and coronary artery disease. Circulation 2008:117:1675-84

10. Desvarieux M, Demmer RT, Rundek T, Boden-Albala B, Jacobs DR Jr, Sacco RL, Papapanou PN. Periodontal microbiota and carotid intima-media thickness: the Oral Infections and Vascular Disease Epidemiology Study (INVEST). Circulation 2005; 111:576-82.

11. Gelskey SC. Cigarette smoking and periodontitis: methodology to assess the strength of evidence in support of a causal association. Community Dent Oral Epidemiol 1999;27:16-24.

12. Stunkard AJ, Foch TT, Hrubec Z. A twin study of human obesity. JAMA 1986:256:51-4.

13. Saremi A, Nelson RG, Tulloch-Reid M, Hanson RL, Sievers ML, Taylor GW, Shlossman M, Bennett PH, Genco R, Knowler WC. Periodontal disease and mortality in type 2 diabetes. Diabetes Care 2005;28:27-32.

14. Ott SJ, El Mokhtari NE, Musfeldt M, Hellmig S, Freitag S, Rehman A, Kühbacher T, Nikolaus S, Namsolleck P, Blaut M, Hampe J, Sahly H, Reinecke A, Haake N, Günther R, Krüger D, Lins M, Herrmann G, Fölsch UR, Simon R, Schreiber S. Detection of diverse bacterial signatures in atherosclerotic lesions of patients with coronary heart disease. Circulation 2006:113:929-37.

15. Chiu B. Multiple infections in carotid atherosclerotic plaques. Am Heart J 1999;138 S534-6.

16. Tonetti MS, D'Aiuto F, Nibali L, Donald A, Storry C, Parkar M, Suvan J, Hingoran $A D$, Vallance $P$, Deanfield $J$. Treatment of periodontitis and endothelial function. N Engl J Med 2007:356:911-20.

17. Helgadottir A, Thorleifsson G, Manolescu A, Gretarsdottir S, Blondal T, Jonasdottir A, Jonasdottir A, Sigurdsson A, Baker A, Palsson A, Masson G, Gudbjartsson DF, Magnusson KP, Andersen K, Levey Al, Backman VM, Matthiasdottir S, Jonsdottir T, Palsson S, Einarsdottir H, Gunnarsdottir S, Gylfason A, Vaccarino V, Hooper WC, Reilly MP, Granger CB, Austin H, Rader DJ, Shah SH, Quyyumi AA, Gulcher JR, Thorgeirsson G, Thorsteinsdottir U, Kong A, Stefansson K. A common variant on chromosome 9 p21 affects the risk of myocardial infarction. Science 2007; 316:1491-3.

18. Wellcome Trust Case Control Consortium. Genome-wide association study of 14,000 cases of seven common diseases and 3,000 shared controls. Nature 2007:447:661-78.

19. Samani NJ, Erdmann J, Hall AS, Hengstenberg C, Mangino M, Mayer B, Dixon RJ, Meitinger T, Braund P, Wichmann HE, Barrett JH, König IR, Stevens SE, Szymczak S, Tregouet DA, lles MM, Pahlke F, Pollard H, Lieb W, Cambien F, Fischer M, Ouwehand 
W, Blankenberg S, Balmforth AJ, Baessler A, Ball SG, Strom TM, Braenne I, Gieger C, Deloukas P, Tobin MD, Ziegler A, Thompson JR, Schunkert H; WTCCC and the Cardiogenics Consortium. Genomewide association analysis of coronary artery disease. N Engl J Med 2007;357:443-53.

20. McPherson R, Pertsemlidis A, Kavaslar N, Stewart A, Roberts R, Cox DR, Hinds DA, Pennacchio LA, Tybjaerg-Hansen A, Folsom AR, Boerwinkle E, Hobbs HH, Cohen JC. A common allele on chromosome 9 associated with coronary heart disease. Science 2007;316:1488-91.

21. Samani NJ, Deloukas P, Erdmann J, Hengstenberg C, Kuulasmaa K, McGinnis R, Schunkert H, Soranzo N, Thompson J, Tiret L, Ziegler A; Coronary Artery Disease Consortium. Large scale association analysis of novel genetic loci for coronary artery disease. Arterioscler Thromb Vasc Biol 2009;29:774-80.

22. Zeggini E, Weedon MN, Lindgren CM, Frayling TM, Elliott KS, Lango $\mathrm{H}$, Timpson NJ, Perry JR, Rayner NW, Freathy RM, Barrett JC, Shields B, Morris AP, Ellard S, Groves CJ, Harries LW, Marchini JL, Owen KR, Knight B, Cardon LR, Walker M, Hitman GA, Morris AD, Doney AS, McCarthy MI, Hattersley AT; Wellcome Trust Case Control Consortium (WTCCC). Replication of genome-wide association signals in UK samples reveals risk loci for type 2 diabetes. Science 2007;316:1336-41.

23. Saxena R, Voight BF, Lyssenko V, Burtt NP, de Bakker PI, Chen H, Roix JJ, Kathiresan S, Hirschhorn JN, Daly MJ, Hughes TE, Groop L, Altshuler D, Almgren P, Florez JC, Meyer J, Ardlie K, Bengtsson Boström K, Isomaa B, Lettre G, Lindblad U, Lyon HN, Melander O, Newton-Cheh C, Nilsson P, Orho-Melander M, Råstam L, Speliotes EK, Taskinen MR, Tuomi T, Guiducci C, Berglund A, Carlson J, Gianniny L, Hackett R, Hall L, Holmkvist J, Laurila E, Sjögren M, Sterner M, Surti A, Svensson M, Svensson M, Tewhey R, Blumenstiel B, Parkin M, Defelice M, Barry R, Brodeur W, Camarata J, Chia N, Fava M, Gibbons J, Handsaker B, Healy C, Nguyen K, Gates C, Sougnez C, Gage D, Nizzari M, Gabriel SB, Chirn GW, Ma Q, Parikh H, Richardson D, Ricke D. Purcell S: Diabetes Genetics Initiative of Broad Institute of Harvard and MIT, Lund University, and Novartis Institutes of BioMedical Research. Genome-wide association analysis identifies loci for type 2 diabetes and triglyceride levels. Science 2007:316:1331-6

24. Scott LJ, Mohlke KL, Bonnycastle LL, Bonnycastle LL, Willer CJ, Li Y, Duren WL, Erdos MR, Stringham HM, Chines PS, Jackson AU, Prokunina-Olsson L, Ding CJ, Swift AJ, Narisu N, Hu T, Pruim R, Xiao R, Li XY, Conneely KN, Riebow NL, Sprau AG, Tong M, White PP, Hetrick KN, Barnhart MW, Bark CW, Goldstein JL, Watkins L, Xiang F, Saramies J, Buchanan TA, Watanabe RM, Valle TT, Kinnunen L, Abecasis GR, Pugh EW, Doheny KF, Bergman RN, Tuomilehto J, Collins FS, Boehnke M. A genome-wide association study of type 2 diabetes in Finns detects multiple susceptibility variants. Science 2007:316:1341-5.

25. Helgadottir A, Thorleifsson G, Magnusson KP, Grétarsdottir S, Steinthorsdottir V, Manolescu A, Jones GT, Rinkel GJ, Blankensteijn JD, Ronkainen A, Jääskeläinen JE, Kyo Y, Lenk GM, Sakalihasan N, Kostulas K, Gottsäter A, Flex A, Stefansson H, Hansen T, Andersen G, Weinsheimer S, Borch-Johnsen K, Jorgensen T, Shah SH, Quyyumi AA, Granger $C B$, Reilly MP, Austin $\mathrm{H}$, Levey Al, Vaccarino V, Palsdottir E, Walters GB, Jonsdottir T, Snorradottir S, Magnusdottir D, Gudmundsson G, Ferrell RE, Sveinbjornsdottir S, Hernesniemi J, Niemelä M, Limet R, Andersen K, Sigurdsson G, Benediktsson R, Verhoeven EL, Teijink JA, Grobbee DE, Rader DJ, Collier DA, Pedersen D, Pola R, Hillert J, Lindblad B, Valdimarsson EM, Magnadottir HB, Wijmenga C, Tromp G, Baas AF, Ruigrok YM, van Rij AM, Kuivaniemi H, Powell JT, Matthiasson SE, Gulcher JR, Thorgeirsson G, Kong A, Thorsteinsdottir U, Stefansson K. The same sequence variant on $9 p 21$ associates with myocardial infarction, abdominal aortic aneurysm and intracranial aneurysm. Nat Genet 2008;40:217-24.

26. Matarin M, Brown WM, Singleton A, Hardy JA, Meschia JF. ISGS investigators. Whole genome analyses suggest ischemic stroke and heart disease share an association with polymorphisms on chromosome 9p21. Stroke 2008;39: 1586-9.

27. Emanuele E, Lista S, Ghidoni R, Binetti G, Cereda C, Benussi L, Maletta R, Bruni AC, Politi P. Chromosome 9p21.3 genotype is associated with vascular dementia and Alzheimer's disease. Neurobiol Aging Published Online First: 2009 Aug 5.

28. Wrensch M, Jenkins RB, Chang JS, Yeh RF, Xiao Y, Decker PA, Ballman KV, Berger M, Buckner JC, Chang S, Giannini C, Halder C, Kollmeyer TM, Kosel ML, LaChance DH, McCoy L, O'Neill BP, Patoka J, Pico AR, Prados M, Quesenberry C, Rice T, Rynearson AL, Smirnov I, Tihan T, Wiemels J, Yang P. Wiencke JK. Variants in the CDKN2B and RTEL1 regions are associated with high-grade glioma susceptibility. Nat Genet 2009;41:905-8.
29. Schaefer AS, Richter GM, Groessner-Schreiber B, Noack B, Nothnagel M, El Mokhtari NE, Loos BG, Jepsen S, Schreiber S. Identification of a shared genetic susceptibility locus for coronary heart disease and periodontitis. PLoS Genet 2009;5: e1000378.

30. Jarinova 0, Stewart AF, Roberts R, Wells G, Lau P, Naing T, Buerki C, McLean BW Cook RC, Parker JS, McPherson R. Functional analysis of the chromosome 9p21.3 coronary artery disease risk locus. Arterioscler Thromb Vasc Biol 2009;29:1671-7.

31. Yap KL, Li S, Munoz-Cabello AM, Raguz S, Zeng L, Mujtaba S, Gil J, Walsh MJ, Zhou MM. Molecular interplay of the noncoding RNA ANRIL and methylated histone H3 lysine 27 by polycomb CBX7 in transcriptional silencing of INK4a. Mol Cell 2010;38:662-74

32. Liu Y, Sanoff HK, Cho H, Burd CE, Torrice C, Mohlke KL, Ibrahim JG, Thomas NE, Sharpless NE. INK4/ARF transcript expression is associated with chromosome 9p21 variants linked to atherosclerosis. PLoS One 2009;4(4):e5027.

33. Broadbent HM, Peden JF, Lorkowski S, Goel A, Ongen H, Green F, Clarke R, Collins R, Franzosi MG, Tognoni G, Seedorf U, Rust S, Eriksson P, Hamsten A, Farrall M, Watkins H. PROCARDIS consortium. Susceptibility to coronary artery disease and diabetes is encoded by distinct, tightly linked SNPs in the ANRIL locus on chromosome 9p. Hum Mol Genet 2008;17:806-14.

34. Schaefer AS, Richter GM, Nothnagel M, Laine ML, Rühling A, Schäfer C, Cordes N, Noack B, Folwaczny M, Glas J, Dörfer C, Dommisch H, Groessner-Schreiber B, Jepsen S, Loos BG, Schreiber SA. 3' UTR transition within DEFB1 is associated with chronic and aggressive periodontitis. Genes Immun 2010;11:45-54.

35. Lao 0, Lu TT, Nothnagel M, Junge O, Freitag-Wolf S, Caliebe A, Balascakova M, Bertranpetit J, Bindoff LA, Comas D, Holmlund G, Kouvatsi A, Macek M, Mollet I, Parson W, Palo J, Ploski R, Sajantila A, Tagliabracci A, Gether U, Werge T, Rivadeneira F, Hofman A, Uitterlinden AG, Gieger C, Wichmann HE, Rüther A, Schreiber S, Becker C, Nürnberg P, Nelson MR, Krawczak M, Kayser M. Correlation between genetic and geographic structure in Europe. Curr Biol 2008;18:1241-8.

36. Steffens M, Lamina C, Illig T, Vogler R, Entz P, Suk EK, Toliat MR, Klopp N, Caliebe A, König IR, Köhler K, Ludemann J, Diaz Lacava A, Fimmers R, Lichtner P, Ziegler A Wolf A, Krawczak M, Nūrnberg P, Hampe J, Schreiber S, Meitinger T, Wichmann HE, Roeder K, Wienker TF, Baur MP. SNP-based analysis of genetic substructure in the German population. Hum Hered 2006;62:20-9.

37. Laine ML, Farre MA, Crusius JB, van Winkelhoff AJ, Peña AS. The mouthwash: a non-invasive sampling method to study cytokine gene polymorphisms. J Periodontol 2000;71:1315-8.

38. de Bakker PI, Yelensky R, Pe'er I, Gabriel SB, Daly MJ, Altshuler D. Efficiency and power in genetic association studies. Nat Genet 2005:37:1217-23.

39. Barrett JC, Fry B, Maller J, Daly MJ. Haploview: analysis and visualization of LD and haplotype maps. Bioinformatics 2005;21:263-5.

40. Krisanaprakornkit S, Weinberg A, Perez CN, Dale BA. Expression of the peptide antibiotic human beta-defensin 1 in cultured gingival epithelial cells and gingival tissue. Infect Immun 1998;66:4222-8.

41. Chung WO, Dommisch H, Yin L, Dale BA. Expression of defensins in gingiva and their role in periodontal health and disease. Curr Pharm Des 2007:13:3073-83.

42. Dommisch H, Chung WO, Rohani MG, Williams D, Rangarajan M, Curtis MA. Dale BAal. Protease-activated receptor 2 mediates human beta-defensin 2 and CC chemokine ligand 20 mRNA expression in response to proteases secreted by Porphyromonas gingivalis. Infect Immun 2007:75:4326-33.

43. Team TRDC. http://www.r-project.org. 2008.

44. Ioannidis JP, Thomas G, Daly MJ. Validating, augmenting and refining genome-wide association signals. Nat Rev Genet 2009;10:318-29.

45. Folkersen L, Kyriakou T, Goel A, Peden J, Mälarstig A, Paulsson-Berne G, Hamsten A. Hugh Watkins, Franco-Cereceda A, Gabrielsen A, Eriksson P; PROCARDIS consortia. Relationship between CAD risk genotype in the chromosome 9p21 locus and gene expression. Identification of eight new ANRIL splice variants. PLoS One 2009; 4:e7677.

46. Pasmant E, Laurendeau I, Heron D, Vidaud M, Vidaud D, Bièche I. Characterization of a germ-line deletion, including the entire INK4/ARF locus, in a melanoma-neural system tumor family: identification of ANRIL, an antisense noncoding RNA whose expression coclusters with ARF. Cancer Res 2007;67:3963-9.

47. Holdt LM, Beutner F, Scholz M, Gielen S, Gäbel G, Bergert H, Schuler G, Thiery J, Teupser D. ANRIL expression is associated with atherosclerosis risk at chromosome 9p21. Arterioscler Thromb Vasc Biol 2010;30:620-7. 


\section{JMG}

CDKN2BAS is associated with periodontitis in different European populations and is activated by bacterial infection

Arne S Schaefer, Gesa M Richter, Henrik Dommisch, Markus Reinartz, Michael Nothnagel, Barbara Noack, Marja L Laine, Mathias Folwaczny, Birte Groessner-Schreiber, Bruno G Loos, Søren Jepsen and Stefan

Schreiber

$J$ Med Genet 2011 48: 38-47 originally published online October 26, 2010 doi: 10.1136/jmg.2010.078998

Updated information and services can be found at:

http://jmg.bmj.com/content/48/1/38

\section{Supplementary Material}

References

Email alerting service
Supplementary material can be found at:

http://jmg.bmj.com/content/suppl/2010/11/01/jmg.2010.078998.DC1.h tml

\section{These include:}

This article cites 45 articles, 23 of which you can access for free at: http://jmg.bmj.com/content/48/1/38\#BIBL

Receive free email alerts when new articles cite this article. Sign up in the box at the top right corner of the online article.

Topic
Collections

Articles on similar topics can be found in the following collections

Drugs: infectious diseases (38)

Diabetes (101)

Epidemiology (585)

Ischaemic heart disease (42)

\section{Notes}

To request permissions go to:

http://group.bmj.com/group/rights-licensing/permissions

To order reprints go to:

http://journals.bmj.com/cgi/reprintform

To subscribe to BMJ go to:

http://group.bmj.com/subscribe/ 